\title{
FLORIAN ZNANIECKI I JANUSZ ZIÓŁKOWSKI O TRADYCJI I KONTYNUACJACH BADAŃ NAD WARTOŚCIOWANIEM PRZESTRZENI MIASTA
}

Celem tego artykułu jest przypomnienie poglądów Floriana Znanieckiego (1852-1958) i Janusza Ziółkowskiego (1924-2000), dwóch oryginalnych tworzących $\mathrm{w}$ różnych okresach, ale połączonych powinowactwem duchowym, twórców poznańskiej socjologii miasta, na problem wartościowania przestrzeni. Nie będzie to oczywiście prezentacja pełnego dorobku obydwu socjologów, a raczej pewna refleksja nad nim i zachęta do korzystania z ich prac we współczesnych dyskusjach dotyczących tożsamości miasta, istnienia centrum miasta czy rewitalizacji przestrzeni miejskiej. Jest to też chęć nawiązania do lat świetności poznańskiej socjologii miasta od 1920 r., czyli czasu powstania akademickiej socjologii w Poznaniu, po długi okres po II wojnie światowej.

\section{I. ÉMILE DURKHEIM, GEORG SIMMEL... I FLORIAN ZNANIECKI - KLASYCY SOCJOLOGII PRZESTRZENI}

Wśród klasyków socjologii zajmujących się przestrzenią miejską wyróżnia się najczęściej Émile’a Durkheima (1858-1917) - najwybitniejszego przedstawiciela socjologizmu, ojca socjologicznego rozumienia przestrzeni. Uważał on, że organizacja przestrzeni odwzorowuje organizację społeczna, dlatego też pojmowanie przestrzeni zmienia się wraz ze zmianami społeczeństwa ${ }^{1}$.

Drugim wśród klasyków socjologii przedstawicielem socjologicznego rozumienia przestrzeni był Georg Simmel (1858-1918), dla którego przestrzeń to dzieło psychiki (eine Tätigkeit der Seele). Simmel był pierwszym niemieckim socjologiem, który opierając się na Kantowskim rozumieniu przestrzeni jako „możliwości spotkań (Möglichkeit des Beisammens), podkreślał znaczenie przestrzeni dla centralnego, jego zdaniem, obiektu zainteresowań socjologii „uspołecznienia” (Vergesellschaftung), rozumianego jako proces wzajemnego oddziaływania pomiędzy ludźmi².

Chociaż w dorobku intelektualnym Simmla problem przestrzeni nie znajduje się na pierwszym planie, to w swoich pracach często do tej kategorii się

${ }^{1}$ É. Durkheim, O podziale pracy społecznej, Warszawa 1999.

2 J. Szacki, Historia myśli socjologicznej, Warszawa 2003, s. 448. 
odwoływał. Najważniejsza wydaje się w tym kontekście praca poświęcona różnym formom uspołecznienia, w której jest rozdział „poświęcony przestrzeni i porządkowi społecznemu"3. Wcześniej, w 1903 r., ukazał się artykuł zatytułowany Socjologia przestrzeni (Soziologie des Raumes) ${ }^{4}$. W tej, jak i w wielu innych pracach, spośród których godzi się wymienić tradycyjnie zaliczaną do socjologii miasta Die Großstädte und das Geistleben ${ }^{5}$ czy Filozofie pieniqdza, podkreślał znaczenie przestrzeni „dla ustalenia norm i symbolicznych zachowań, dla związków i wzajemnego oddziaływania pomiędzy ludźmi i grupami społecznymi”'.

Wzajemne oddziaływanie na siebie ludzi Simmel traktował jako „wypełnianie przestrzeni” (Die Wechselwirkung unter Menschen als Raumerfüllung). Z kolei izolowanie się, brak interakcji powoduje, że powstaje „niewypełniona przestrzeń”: „Jeśli pewna liczba osób zamieszkujących określoną przestrzeń jest wobec siebie izolowana, to wprawdzie każda z nich wypełnia sobą i swoimi czynnościami określona przestrzeń, ale pomiędzy ta przestrzenia a przestrzenią sasiada pozostaje niewypełniona przestrzeń, praktycznie mówiąc »nic«"7.

Simmel dodaje jednak przewrotnie, że nie jest uzasadnione znaczenie

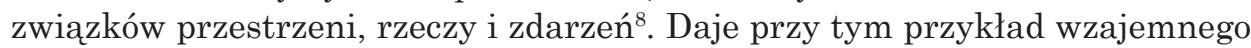
oddziaływania pomiędzy ludźmi, które poza definicyjnym znaczeniem można traktować jako wypełnianie przestrzeni ${ }^{9}$. Takie ujęcie pozwala Simmlowi stwierdzić, że przestrzeń, będąc dziełem psychiki, jest jednocześnie mniej lub bardziej wstępnym etapem każdej społecznej organizacji. W Filozofii pieniq$d z a$ podkreśla, że rozwój gospodarki pieniężnej wpłyną z jednej strony na skupienie aktywności społecznej w centrach miejskich, z drugiej - powiązał określone kategorie struktury społecznej, w pełnym tego słowa znaczeniu, $\mathrm{z}$ kategoria przestrzeni ${ }^{10}$. Do tych poglądów na życie w mieście nawiązał twórca szkoły chicagowskiej - Robert Ezra Park, dla którego przestrzeń to nie tyle możliwość życia we wspólnocie, ile „warunek tworzenia naturalnych stref łączących przestrzeń i kulturę"11.

Fundamentalne zasługi dla socjologicznego rozumienia przestrzeni położyli, nawiązując do Maksa Webera i Georga Simmla, badacze szkoły chicagowskiej (obok Roberta E. Parka byli to m.in. William Burgess i Robert Redfield), którzy zajmowali się analizą miejskiej przestrzeni miast amerykańskich i zachodzacych w nich pod wpływem masowej migracji zjawisk i procesów. Głównym

${ }^{3}$ G. Simmel, Der Raum und die räumlichem Ordnung der Gesellschaft, w: Soziologie Untersuchungen über die Formen der Vergesellschaftung, Berlin 1908, s. 460-526.

${ }^{4}$ G. Simmel, w „Jahrbuch für Gesetzgebung, Verwaltung und Volkswirtschaft im Deutschen Reich", t. 27, s. 27-71. Wydany w języku polskim pt. Socjologia przestrzeni, w: G. Simmel, Pisma socjologiczne, Scholar, Warszawa 2008, s. 365-386.

${ }^{5}$ Wydanie polskie: G. Simmel, Mentalności mieszkańców wielkich miast, tłum. M. Łukaszewicz, w: idem, Most $i$ drzwi, Warszawa 2006.

${ }^{6}$ P. Noller, Globalisierung, Raum und Gesellschaft: Elemente einer modernen Soziologie des Raumes, „Berliner Journal für Soziologie” 2000, nr 1, s. 27.

${ }^{7}$ G. Simmel, Der Raum..., s. 462.

8 Ibidem.

${ }^{9}$ Ibidem

${ }^{10}$ R. E. Park, W. Burgess, R. D. McKenzi, R. Wirth, The City, Chicago-London 1925, s. 95.

${ }^{11}$ Ibidem. 
przedmiotem ich zainteresowań były procesy aglomeracyjne, takie jak centralizacja, koncentracja, segregacja, inwazja, sukcesja, rywalizacja, kooperacja, wymiana $^{12}$.

W Polsce prekursorem socjologicznego rozumienia przestrzeni był Florian Znaniecki (1882-1958) ${ }^{13}$. W napisanym w 1938 r. eseju Socjologiczne podstawy ekologii ludzkiej zwraca uwagę na humanistyczne znaczenie przestrzeni, bo to przecież ludzie wartościują przestrzeń i wyznaczają sposób, w jaki ja użytkują. Jego zainteresowania ogniskowały się wokół problemu postrzegania przestrzeni z punktu widzenia badacza kultury, który w odróżnieniu od matematyka czy fizyka „musi brać przestrzeń jak wszystko, z czym ma do czynienia - jak układ językowy, mit, ceremoniał, kompozycję muzyczna, obraz, narzędzie, pieniądz - z jej współczynnikiem humanistycznym, tj. tak, jak jest doświadczana przez te podmioty ludzkie, których kulturę bada"14.

Znaniecki uważa przy tym, że dla humanisty lepszym niż wyraz „przestrzeń” jest termin „wartość przestrzenna”, który oznaczać miałby całą klasę różnych konkretnych przestrzeni:

Wyrazu „przestrzeń” humanista powinien więc używać tylko w znaczeniu generycznym, dla oznaczenia całej klasy tych konkretnych, poszczególnych „przestrzeni”. Może nawet lepiej byłoby utworzyć specjalny termin generyczny, np. „wartość przestrzenna”. Takie „przestrzenie” czy „wartości przestrzenne” to np. miejsca zajęte lub puste, wnętrza przestronne lub ciasne i w przeciwieństwie do nich „zewnętrza”, siedziby, okolice, ośrodki, granice, tereny wymierzone, przestworza niewymierne, „strony” (przód, tył, prawa, lewa, góra, dół), „strony świata”, dalekości, bliskości, perspektywy, drogi, bezdroża itp. ${ }^{15}$

W eseju o ekologii ludzkiej Znaniecki rozpatruje niektóre z tych wartości jako elementy pewnych systemów społecznych (religijnego, społecznego, estetycznego, ekonomicznego). Uważa, że w ten dopiero sposób przedstawić można problem umiejscowienia jednostek w przestrzeni z punktu widzenia socjologii. Zakłada przy tym, że wszystkie zespoły ludzkie traktują pewne wartości przestrzenne jako „swoje” w tym sensie, że „władają” nimi dla wykonania pewnych czynności zbiorowych i umożliwiają też swoim członkom wykonanie pewnych czynności jednostkowych ${ }^{16}$. Znaniecki podaje przykład państwa (grupy państwowej), dla którego wspólną wartością przestrzenną jest terytorium całego państwa, a każdy jej członek „ma prawo do obecności w tej wartości przestrzennej"17.

Przyznawane jednostce prawo obecności w pewnej przestrzeni wchodzi zdaniem Znanieckiego - w skład jego stanu socjalnego, który obejmuje dwa rodzaje praw: prawo do utrzymania „pozycji materialnej” (ekonomicznej) i pra-

12 Por. B. Jałowiecki, M. Szczepański, Miasto i przestrzeń w perspektywie socjologicznej, Warszawa 2006, s. 19.

13 Szerzej o dorobku poznańskiej socjologii miasta, zob. S. Lisiecki, J. Kubera (red.), Odkrywanie systemu miasta. Miasto w socjologii poznańskiej 1920-2000, Poznań (w druku).

${ }^{14}$ F. Znaniecki, Socjologiczne podstawy ekologii ludzkiej, „Ruch Prawniczy, Ekonomiczny i Socjologiczny" 1938, z. 1, s. 90.

15 Ibidem, s. 91.

16 Ibidem.

17 Ibidem, s. 93. 
wo do „uczestnictwa w wartościach duchowych” (pozycję moralna). Znaniecki uważa, że wartości przestrzennych nie można sprowadzić do wartości ekonomicznych, chociaż są one z nimi w sposób oczywisty związane:

Proponujemy więc dla przyznawanego człowiekowi w pewnej roli społecznej prawa obecności w pewnej przestrzeni specjalny termin: p o z y cj a e k olog i c zna. [...] Najlepiej znane i, być może, genetycznie najpierwotniejsze pozycje ekologiczne są te, które jednostkom nadają kręgi rodzinne. U ludów o względnie luźnej strukturze społecznej, na różnych zresztą szczeblach cywilizacji, zespoły rodzinne mają znaczną samodzielność w stosunku do obszerniejszych ugrupowań. Ich wspólne wartości przestrzenne - nazwijmy je ogólnie „siedzibami rodzinnymi” - sa w wyłącznym prawie ich władaniu. Obejmują one ośrodki mieszkalne - obozowiska, domy, kompleksy domów; oraz tereny funkcjonowania ekonomicznego myślistwa, zbierania owoców, rybołówstwa, pasterstwa, rolnictwa, przemysłu ${ }^{18}$.

Do grup nadrzędnych Znaniecki zalicza zespoły lokalne (w tym gminę wiejska) i zespoły ponadlokalne (państwo, Kościól, naród). „Wartość państwowa” jest dla Znanieckiego największa i najbardziej oczywista, chociaż, jak przyznaje, ,jest to tylko część problemu, gdyż wpływ ekologiczny państwa krzyżuje się i kombinuje z wpływem narodów, Kościołów, związków klasowych ${ }^{19}$. Dotyczy to także pozycji ekologicznej obcych, w obrębie terytorium państwowego:

Ewolucja postawy państwa względem „obcych” potwierdzać się zdaje to przypuszczenie, że w miarę ustalania się typu państwa jako grupy specyficznie terytorialnej uczestnictwo jednostki w wartościach przestrzennych państwa, znaczenie, jakie jej obecność posiada dla terytorium państwowego, determinuje cała jej rolę w grupie państwowej. Podobnie jak zespół rodzinny i lokalny państwo zasadniczo nie dopuszcza obcych do obrębu swego terytorium; podobnie jak tamte zespoły czyni wyjattki od tej zasady dla jednostek przybywających w pewnych wyznaczonych rolach, podobnie też, jak tam, role te sprowadzają się do trzech wzorów: gości, sług-przybłędów oraz członków przybranych ${ }^{20}$.

Do powyższych założeń metodologicznych nawiązał Znaniecki w konkursie „Czym było i jest dla Ciebie miasto Poznań?”, ogłoszonym w 1928 r. w czasie Powszechnej Wystawy Krajowej. Efektem tego konkursu była książka Miasto w świadomości jego obywateli, wydana w 1931 r. w Poznaniu. Była to jednocześnie prezentacja poglądów Znanieckiego - krytyka szkoły ekologicznej i jednego z twórców ujęcia kulturalistycznego w socjologii miasta, definiującego miasto jako całość nieprzestrzenna, humanistyczna, realizująca się w doświadczeniu i działaniu ludzkim ${ }^{21}$. Jak piszą Marek S. Szczepański i Bohdan Jałowiecki: „Innymi słowy, używając metaforyki Znanieckiego, badać miasto to analizować jego zindywidualizowany odbiór, odczytywać wartościowanie, ale też docierać do podejmowanych działań, czyli - w terminologii klasyka czynności”22.

\footnotetext{
18 Ibidem, s. 94-95.

19 Ibidem, s. 112.

${ }^{20}$ Ibidem, s. 117.

21 B. Jałowiecki, M. S. Szczepański, op. cit., s. 21.

22 Ibidem, s. 27.
} 
Układ odniesienia konkursu „Czym było i jest dla Ciebie miasto Poznań?” stanowiła odezwa, która ukazała się w gazetach poznańskich i w formie ogłoszeń wieszanych na słupach informacyjnych. Tekst tej odezwy brzmiał następująco:

Do Mieszkańców Poznania! Polski Instytut Socjologiczny ogłasza konkurs na najlepszą odpowiedź na pytanie: „Czym było i jest dla Ciebie miasto Poznań?”. I nagroda 500 zł, II nagroda 300 zł, III nagroda 200 zł, IV nagroda $100 \mathrm{zł.}$

Do udziału w konkursie bardzo proszeni są wszyscy mieszkańcy najmniej od roku przebywający w Poznaniu, mężczyźni i kobiety, bez różnicy wykształcenia, zajęcia i zamożności. Błędy pisowni, zły styl, brzydkie pismo nie stanowią żadnych przeszkód do uzyskania nagrody. Odpowiedzi oceniane będą tylko ze względu na ich s z c z e r o ść, dokładność i szczegółowość.

Jeżeli nadesłana będzie znaczna ilość odpowiedzi, Instytut za zgodą autorów ogłosi drukiem w osobnej książce nie tylko te, które dostaną nagrody, ale wszystkie, które Komitet Konkursowy wyróżni.

Każda odpowiedź powinna obejmować najmniej 40 stron pisma (im więcej tym lepiej) i zawierać następujące wiadomości:

- Krótki życiorys piszącego.

- Opis wszystkich styczności, jakie piszący miał z instytucjami miejskimi (Magistratem, Radą Miejska, policją miejską i budowlaną, zakładami dobroczynnymi, zdrowotnymi, urzędami podatkowymi itd.).

- Co piszący robił w swoim życiu na korzyść miasta Poznania (podatki, jakie płacił, dobrowolne świadczenia, piastowanie urzędów płatnych i honorowych, uczestnictwo w wyborach, zgromadzeniach, praca najemna w biurach i przedsiębiorstwach miejskich, przyczynki do wyglądu miasta itd.)?

- Jakie korzyści piszący zawdzięcza miastu Poznaniowi (użytkowanie zakładów, urządzeń, instytucji miejskich, zarobki, wsparcie, pomoc wychowaniu dzieci, opieka policyjna i prawna, opieka lekarska itd.)?

- Jakie szkody mimowolnie lub świadomie piszący przyczynił miastu?

- Jakich krzywd piszaccy doznał od miasta?

- Czy piszacy uważa siebie za moralnego dłużnika miasta czy té̇, przeciwnie, sądzi że mniej otrzymał od miasta niż dał miastu?

- Co piszącego skłania do pobytu w Poznaniu (interesy ekonomiczne, pokrewieństwa, przyjaźnie i znajomości, przyzwyczajenia osobiste, przywiązanie do miasta, itd.)?

- Co piszącego zniechęca do pobytu w Poznaniu?

- Jakie jest zdanie piszącego o ludności Poznania w ogóle? O poszczególnych klasach ludności (robotnikach, rzemieślnikach, kupcach, przemysłowcach, urzędnikach, dziennikarzach, literatach, artystach, duchowieństwie)? O pannach i mężatkach? O dzieciach?

- Jakie jest zdanie piszącego o zarządzie miasta (prezydencie, Radzie Miejskiej, Magistracie, urzędach)?

- Co sądzi piszący o przedsiębiorstwach i imprezach miejskich?

- Co sądzi piszący o Tragach Poznańskich i Powszechnej Wystawie Krajowej?

- Jakie jest zdanie piszącego o zewnętrznym wyglądzie Poznania?

- Jakie inne miasta zna piszący dobrze? Czy woli Poznań, czy które inne miasto i dlaczego?

- Jak się różni Poznań dzisiejszy od przedwojennego (jeżeli piszący mieszkał przed wojną w Poznaniu)?

- Jakie są najważniejsze i najpotrzebniejsze potrzeby Poznania i jak im uczynić zadość?

- Jaki musiałby się stać Poznań, aby stać się ideałem miasta?

Rękopisy nadsyłać należy do dnia 15 stycznia 1929 r. pod adresem: Polski Instytut Socjologiczny - Poznań-Uniwersytet. 
Rękopis powinien być podpisany nie własnym nazwiskiem piszącego, lecz godłem lub pseudonimem; nazwisko i adres powinno być dołączone w zamkniętej kopercie, zaopatrzonej w to samo godło, co rękopis. Nadesłane rękopisy pozostają własnością Instytutu.

Ogłoszenie wyniku konkursu nastapi dnia 1 marca 1929.

Instytut udziela wszelkich porad w sprawie powyższego konkursu ${ }^{23}$.

Otrzymano 27 wypowiedzi, spośród których najwięcej dotyczyło ocen i opinii o ludności Poznania. Jak pisał Znaniecki: „Autorowie nasi mają widocznie o wiele więcej do powiedzenia o swoich współobywatelach niż o mieście jako całości, stosunki między jednostkami prywatnymi żywotniejsze są w ich oczach niż stosunki jednostki i gminy lub obywatela i funkcjonariusza gminnego"24.

Książkę Miasto w świadomości jego obywateli recenzował uczeń Floriana Znanieckiego - Tadeusz Szczurkiewicz. W zamieszczonej w „Ruchu Prawniczym, Ekonomicznym i Socjologicznym" (z. 3/1931) recenzji tak pisał o pracy swojego mistrza:

\footnotetext{
„Miasto w świadomości jego obywateli jest pierwszą” w socjologii polskiej $1^{0}$ pracą w dziedzinie socjologji wielkiego miasta; wydana przed kilkunastu laty praca Z. Dębickiego pt. „Miasteczko" ujmowała zagadnienia drobnych miast z punktu widzenia raczej publicystyc zneg o. $2^{0}$ Próbą analizy socjologicznej danych uzyskanych przez ankietę. Z tego względu posiada ona przede wszystkiem wartość metodologiczna, demonstrując na konkretnym przykładzie, w jaki sposób socjologja może i powinna korzystać z materjału dostarczonego jej przez wypowiedzi członków pewnej grupy ${ }^{25}$.
}

\section{JANUSZ ZIÓŁKOWSKI. KONTYNUACJA I ROZWIJANIE DOROBKU FLORIANA ZNANIECKIEGO}

Po 1945 r. zainteresowania teoretyczno-badawcze pracowników poznańskiej Katedry Socjologii ukierunkowane były na analizę przemian zachodzacych w powojennej Polsce wskutek uprzemysłowienia i urbanizacji. W tym nurcie działała również poznańska socjologia miasta, rozwijająca się jako odrębna subdyscyplina. Inicjatorem prac seminarium socjologii miasta był Janusz Ziółkowski, autor pionierskiej pracy Urbanizacja. Miasto. Osiedle. Studia socjologiczne $e^{26}$.

$\mathrm{Z}$ punktu widzenia problematyki przestrzeni $\mathrm{w}$ przedstawionym zbiorze studiów szczególną uwagę zwraca rozdział zatytułowany „O socjologiczną wyobraźnię urbanisty"27, w którym Ziółkowski pisze o 4 elementach:

1) świadomości, że planowanie urbanisty jest działaniem społecznym,

2) świadomości, że konieczne jest zapoznanie się z przebiegiem różnorakich procesów społecznych, które zachodzą w grupach, w których żyją mieszkańcy danego miasta, ich preferencji i postaw,

${ }^{23}$ F. Znaniecki, Miasto w świadomości jego obywateli. Z badań Polskiego Instytutu Socjologicznego nad miastem Poznaniem, Poznań 1931, s. 12-13.

${ }^{24}$ Ibidem, s. 75

${ }^{25}$ T. Szczurkiewicz, Znaniecki, Florjan: Miasto w świadomości jego obywateli [recenzja], „Ruch Prawniczy, Ekonomiczny i Socjologiczny” 1931, z. 3, s. 717-718.

${ }^{26}$ J. Ziółkowski, Urbanizacja. Miasto. Osiedle. Studia socjologiczne, Warszawa 1965.

${ }^{27}$ Ibidem, s. 227-253. 
3) świadomości, że działanie urbanisty powoduje konkretne skutki społeczne, pozwalające na zaspokojenie potrzeb i aspiracji mieszkańców,

4) świadomości faktu, że działanie urbanisty jest zdeterminowane przez jego pochodzenie i doświadczenie życiowe ${ }^{28}$.

Powołuje się przy tym na przykłady zaczerpnięte z prac klasyków socjologii miasta, w tym twórce kierunku neoekologicznego - Louisa Wirtha - dla którego „planowanie urbanistyczne polega na tworzeniu, przy pomocy racjonalnych środków, formy fizycznej, która by umożliwiła ludziom tak pełne rozwiązanie ich problemów i spełnienie ich nadziei, jak tylko na to pozwola ich zasoby, twórcza wyobraźnia i zdyscyplinowana inteligencja”"29. Nawiąując do twórcy rozumienia miasta jako „stylu życia”, Ziółkowski uważa, że każdy urbanista powinien sobie postawić pytanie:

\begin{abstract}
Najpierw, czy miasta w ogóle są nam potrzebne? Dlaczego chcemy w nich żyć? Czy uzyskujemy w nich to, co pragnęliśmy uzyskać? Jakie sa korzyści i niekorzyści miejskiego życia? Jakie sa inspiracje i wartości ludzi, dla których działalność urbanistyczna jest prowadzona? Jaką rolę ma pełnić centrum miejskie, przedmieście, miasto-satelita czy strefa podmiejska w życiu społeczności miejskiej pojętej jako spójna funkcjonalna całość? Jaka jest struktura i jakie są funkcje rodziny oraz jakie tu występują tendencje rozwojowe? Czy możliwe jest istnienie w mieście więzi sąsiedzkiej? Jakie sa grupy społeczne, w których żyje człowiek miejski i w których zaspokaja swoje socjopsychiczne potrzeby? Na czym polega istota miejskich stosunków społecznych? Jaki wyraz przestrzenny znajduje miejska heterogeniczność i ruchliwość społeczna? ${ }^{30}$
\end{abstract}

W każdej próbie odpowiedzi na postawione wyżej pytania, uważa Ziółkowski, pomocna winna być wyobraźnia socjologiczna, która pozwoli urbanistom na pewną wizję współżycia społecznego w projektowanych jednostkach i przewidywanie społecznych konsekwencji ich pracy, bez czego „ich twórczość byłaby wręcz niemożliwa" ${ }^{31}$.

W 1963 r. powstało seminarium socjologii miasta, w ramach którego prowadzono badania przemian miast polskich po II wojnie światowej. Ich efektem były m.in. prace Poznań. Społeczno-przestrzenne skutki industrializacji ${ }^{32}$ i Sosnowiec: drogi i czynniki rozwoju miasta przemystowego ${ }^{33}$.

We wstępie do opartej na bogatym materiale dokumentacyjnym pracy o Sosnowcu profesor filozofii i prawnik Czesław Znamierowski napisał:

Autor interesującej pracy o Sosnowcu starannie przygotował się do niej swymi studiami w zakresie ekonomiki i socjologii oraz działalnością praktyczną w zarządzie jednego z większym miast Polski, Poznania. Studia ekonomiczne zwróciły uwagę na życie gospodarcze miasta, a związki osobiste z Sosnowcem, skąd właśnie Autor pochodzi, sprawiły, że jako pierwszy przedmiot swoich badań socjograficznych wybrał miasto rodzinne, które w pracy tej przedstawia nie tylko na rozległej podstawie dokumentarnej, lecz odtwarza jego stosunki społeczne i gospodarcze również z własnej autopsji. Ta bezpośrednia, dawna i stała styczność Autora z opisywanym miastem wyszła ze wszech miar na dobre pracy o Sosnowcu. Czuje się na każ-

\footnotetext{
28 Ibidem, s. 229.

${ }^{29}$ L. Wirt, za: J. Ziółkowski, Urbanizacja. Miasto..., s. 234.

30 Ibidem, s. 234-235.

31 Ibidem, s. 243.

32 J. Ziółkowski (red.), Poznań. Społeczno-przestrzenne skutki industrializacji, Warszawa 1967.

${ }^{33}$ Idem, Sosnowiec. Drogi i czynniki rozwoju miasta przemystowego, Katowice 1966.
} 
dym niemal kroku jego wywodów, że Autor mówi o rzeczach znanych sobie naocznie. Z tym się też wiąże żywy, dynamiczny tok wykładu, w którym są skrystalizowane długie rozważania tego tematu ${ }^{34}$.

Dla Ziółkowskiego jako socjologa miasto to „grupa ludzi, która mieszka w murach miejskich" ${ }^{35}$. Podkreśla tym samym, że tworzenie i rozwój społeczności miejskiej są nierozerwalnie związane z przestrzenią. Staje w ten sposób w opozycji do Znanieckiego, dla którego miasto to całość nieprzestrzenna, humanistyczna, realizująca się w doświadczeniu i działaniu ludzkim ${ }^{36}$. Ziółkowski konsekwentnie też dowodzi, że rozumienie miasta zaproponowane przez autora Miasta w świadomości nie może stanowić dyrektywy metodologicznej dla współczesnej socjologii miasta. Uważa, podobnie jak główni przedstawiciele ujęcia ekologicznego, Park i Burgess, że przestrzeń, obok systemu społecznego, stanowi część składową socjologicznie rozumianego miasta.

Jednostka, dążąc do znalezienia sobie w obrębie przestrzeni miejskiej jak najlepszego miejsca, odpowiadającego jej indywidualnym i społecznym potrzebom, ma tendencję do zamieszkiwania wespół z członkami grupy miejskiej, jednorodnymi z nią pod określonym względem. Fakt zamieszkiwania danej ulicy czy dzielnicy miasta przez takie czy inne jednostki, przynależące do określonych grup społecznych, jest w pierwszym rzędzie zdeterminowany ekonomicznie. Ale działają tu również wtórne czynniki pozaekonomiczne. Jednym z nich jest tradycja czy konserwatyzm, nakazujące zamieszkiwać dane partie miasta, mimo że znikły już korzyści ekonomiczne i społeczne, które kiedyś ten wybór usprawiedliwiały ${ }^{37}$.

Tendencje do znalezienia sobie $\mathrm{w}$ przestrzeni miejskiej jak najlepszego miejsca (mówiąc językiem Znanieckiego - „pozycji ekologicznej”), ujawniły się także w Sosnowcu, czego przykładem mogła być segregacja przestrzenna ludności żydowskiej, zamieszkujacej zwartą enklawę ograniczoną kilkoma ulicami. W tym miejscu dodać jeszcze można, że był to jeden z przykładów procesów aglomeracyjnych, którymi interesowała się ekologia społeczna (obok procesu centralizacji, koncentracji, inwazji oraz sukcesji) ${ }^{38}$.

Wspólna natomiast, zarówno u Znanieckiego, jak i Ziółkowskiego, okazała się skłonność do korzystania z materiałów o charakterze dokumentów osobistych, do traktowania przestrzeni miejskiej ze współczynnikiem humanistycznym (wartościowanie przestrzeni). Znalazło to swój wyraz w ogłoszonym w 1964 r. przez Katedrę Socjologii Uniwersytetu im A. Mickiewicza w Poznaniu konkursie „Czym jest dla Ciebie miasto Poznań?”. Odniesiono się w ten sposób do poprzedniego konkursu ogłoszonego przez Znanieckiego w $1928 \mathrm{r}$. Zastosowano metodę badania mieszkańców tego samego miasta po upływie pewnego czasu, w ten sposób nawiązano do badań małżeństwa Roberta S. i Helen M. Lyndów prowadzonych w latach dwudziestych i trzydziestych XX w. w amerykańskim

\footnotetext{
${ }^{34}$ Cz. Znamierowski, „Wstęp”, w: J. Ziółkowski, Sosnowiec. Drogi i czynniki rozwoju..., s. 9.

35 Ibidem.

${ }^{36}$ F. Znaniecki, Miasto w świadomości jego obywateli..., s. IX.

37 J. Ziółkowski, Sosnowiec. Drogi i czynniki rozwoju..., s. 190.

38 B. Jałowiecki, M. Szczepański, op. cit., s. 19.
} 
mieście znanym jako Middletown ${ }^{39}$; w Polsce - metodę panelową stosował Franciszek Bujak w badaniach prowadzonych w małopolskiej wsi Żmiąca ${ }^{40}$.

Podobnie jak w badaniach Znanieckiego, uczestnikom konkursu postawiono, obok zasadniczego pytania, czym jest dla każdego z nich miasto Poznań, szereg pytań, które organizatorom konkursu wydały się ważne dla ukazania aktualnych zjawisk i tendencji społecznych. Kwestionariusz konkursu obejmował następujace pytania:

1. O czym byś pomyślał, gdyby Cię zapytać: co w Poznaniu jest najbardziej „poznańskie” (co uważasz za symbol miasta)?

2. Czy uważasz Poznań za wielkie miasto? Jeśli tak, to na czym, Twoim zdaniem, polega wielkomiejskość Poznania? Jakie instytucje poznańskie, według Ciebie, mają ogólnopolskie znaczenie?

3. Czy Poznań jest dla Ciebie miastem nowoczesnym? Która część miasta najbardziej Ci się podoba i dlaczego? Gdzie lokalizujesz i co sądzisz o centrum Poznania?

4. Co sądzisz o kierunkach i tempie rozwoju gospodarczego, kulturalnego i architektoniczno-urbanistycznego naszego miasta w okresie powojennym?

5. Jakie zmiany w Poznaniu w ciąu minionych 19 lat uważasz za najważniejsze?

6. Jakim miastem jest dla Ciebie Poznań z punktu widzenia funkcji, które pełni i składu społecznego ludności?

7. Jak oceniasz Poznań na tle innych, znanych Ci w Polsce miast? Czym Poznań różni się od tych miast, w czym podoba Ci się więcej, w czym mniej?

8. Co sądzisz o mieszkańcach naszego miasta (o „starych” i „nowych”, robotnikach i inteligentach, o kobietach i mężczyznach, studentach i młodzieży)? Czy, Twoim zdaniem, istnieją cechy wspólne wszystkich mieszkańców Poznania?

9. Czy czujesz się poznaniakiem? Co Cię najbardziej wiąże z tym miastem?

10. Czy w Poznaniu znajdujesz i widzisz możliwość zaspokojenia wszystkich swoich potrzeb materialnych i kulturalnych?

11. Czy chciałbyś wywędrować z Poznania? Jeśli tak, to dokąd i dlaczego?

12. Z jakim środowiskiem najczęściej utrzymujesz kontakty (z członkami bliższej i dalszej rodziny, kolegami z zakładu pracy, innymi znajomymi i przyjaciółmi)? Z kim jeszcze?

13. Podziel się uwagami na temat swych kontaktów z kierownictwem swego zakładu pracy, instytucjami poznańskimi, przedstawicielami władz miejskich ${ }^{41}$.

W zebranych w konkursie wypowiedziach, podobnie jak w konkursie z 1928 r., sporo miejsca zajęła charakterystyka samych mieszkańców Poznania, przedstawiana zarówno przez rdzennych mieszkańców, jak i tych „napływowych”, którzy przybyli z innych regionów Polski ${ }^{42}$. Wśród pozytywnych cech „poznańskości” wymieniano najczęściej: „pracowitość, gospodarność, rzetelność, kult dobrej roboty, solidarność, oszczędność, zdyscyplinowanie, zamiłowanie do porządku, poczucie realizmu, koleżeństwo, poczucie sprawiedliwości, uczucia rodzinne, wczesne zakończenie dnia, przedkładanie kultury domowej

${ }^{39}$ R. S. Lynd, H. M. Lynd, Middletown: A Study in Contemporary American Culture, Harcourt Brace and Company, New York 1929; iidem, Middletown in Transition: A Study in Cultural Conflicts, Harcourt Brace and Company, New York 1937.

${ }^{40}$ F. Bujak, Żmiqca. Wieś powiatu limanowskiego. Stosunki gospodarcze $i$ spoteczne, Gebethner i Spółka, Kraków 1903; Z. T. Wierzbicki, Żmiaca w pół wieku później, Ossolineum, Wydawnictwo PAN, Instytut Filozofii i Socjologii PAN, Zakład Socjologii Wsi, Wrocław-Warszawa-Kraków 1963.

${ }^{41}$ F. Znaniecki, J. Ziółkowski, Czym jest dla Ciebie miasto Poznań? Dwa konkursy: 1928/ 1964, PWN, Warszawa-Poznań 1984, s. 195-196.

${ }^{42}$ Ibidem, s. 198. 
nad imprezowa” ${ }^{43}$. Do cech negatywnych „poznańskich” cech zaliczono: „konserwatyzm, zbyt uroczyste podejście do spraw codziennych i oczywistych, nadto duże liczenie się z litera prawa (co to 'porządek musi być'), pedantyzm, formalizm, 'niesympatyczność', nieumiejętność cieszenia się chwila, 'ciułanie' ('Wieloletni uporny harunek przy najskromniejszym trybie życia, odmawianie sobie przez wiele lat rozrywek [...] głównym elementem poznańskości’ [...]), brak polotu, fantazji, ale też i brak umiejętności reklamowania swych osiagnięćc" ${ }^{44}$.

W odpowiedzi zaś na pytanie o „najbardziej poznańskie” obiekty - symbole miasta wskazywano najczęściej:

Tabela

Symbole miasta Poznania (1964)

\begin{tabular}{|c|c|c|c|c|c|c|}
\hline \multirow[b]{2}{*}{ Obiekt $^{*}$} & \multicolumn{5}{|c|}{ Symbol } & \multirow[b]{2}{*}{ Razem } \\
\hline & częściowy & wyłączny & pierwszy & dalszy & $\begin{array}{l}\text { w kon- } \\
\text { tekście }\end{array}$ & \\
\hline Ratusz & 11 & 20 & 13 & 8 & 5 & 57 \\
\hline Koziołki ratuszowe & 4 & 2 & 2 & 4 & 10 & $22\left(64^{* *}\right)$ \\
\hline Orzeł ratuszowy & 1 & & & & 6 & 7 \\
\hline Hejnał ratuszowy & & & 1 & & & 1 \\
\hline $\begin{array}{l}\text { Międzynarodowe } \\
\text { Targi Poznańskie }\end{array}$ & 10 & 14 & 3 & 11 & & 38 \\
\hline Wieża Górnośląska & 1 & & & 1 & & 2 \\
\hline $\begin{array}{l}\text { Stare Miasto } \\
\text { (Stary Rynek) }\end{array}$ & 2 & 6 & 2 & 3 & 3 & 16 \\
\hline Katedra & 2 & 1 & 4 & 8 & 1 & 16 \\
\hline ZPM „H. Cegielski” & 2 & & & 6 & & 8 \\
\hline Opera & 2 & 1 & 1 & 3 & & 7 \\
\hline Zamek & & 2 & 1 & 3 & & 6 \\
\hline Biblioteka Raczyńskich & & & & 4 & 1 & 5 \\
\hline Collegium Minus & & & 1 & 3 & & 4 \\
\hline Kościoły (poza katedra) & & & & 3 & 1 & 4 \\
\hline Chór Stuligrosza & & 1 & & 2 & & 3 \\
\hline Hotel „Merkury” & 2 & & & 1 & & 3 \\
\hline Hotel „Warta” & & & 1 & 2 & & 3 \\
\hline Hotel „Bazar” & & & & 1 & 1 & 2 \\
\hline Teatr Polski & 1 & & & & 1 & 2 \\
\hline Muzea & & & & 2 & & 2 \\
\hline Ogród Zoologiczny & 1 & & & 1 & & 2 \\
\hline $\begin{array}{l}\text { Nazwa miasta } \\
\text { (jej interpretacja) }\end{array}$ & & 1 & & & & 1 \\
\hline Herb miasta & & 1 & 1 & & & 2 \\
\hline
\end{tabular}

* Obiekty i instytucje wymienione tylko raz uwzględniono w przypadku, gdy stanowiły symbol wyłączny lub pierwszy.

** Liczba respondentów jest niższa niż suma wzmianek, ponieważ kilka osób wymieniło równocześnie i sam gmach, i jego najbardziej charakterystyczny element.

Źródło: F. Znaniecki, J. Ziółkowski, op. cit., s. 203.

\footnotetext{
43 Ibidem.

${ }^{44}$ Ibidem, s. 199.
} 


\section{W NAWIĄZANIU DO TRADYCJI}

Powstaje w tym miejscu pytanie, czy przypomniane powyżej prace Znanieckiego i Ziółkowskiego i ich rozważania nad wartościowaniem przestrzeni znalazły (czy też znaleźć moga) zastosowanie we współczesnych badaniach nad miastami polskimi. Przykładem wykorzystania ich dorobku sa badania Ryszarda Cichockiego i Krzysztofa Podemskiego przeprowadzone trzydzieści lat po badaniu Janusza Ziółkowskiego ${ }^{45}$. W odpowiedzi na pytanie dotyczące najważniejszych symboli miasta wymieniano najczęściej: atrakcyjne osobliwości turystyczne (Koziołki, Palmiarnia), zabytki (Stare Miasto, Katedra, Fara, Zamek Cesarski), instytucje gospodarcze (Międzynarodowe Targi Poznańskie, Zakłady Cegielskiego), instytucje i wydarzenia kulturalne (Opera, Muzeum Narodowe, Konkurs Skrzypcowy im. H. Wieniawskiego, chóry chłopięce), wyższe uczelnie (Uniwersytet, Akademia Ekonomiczna), charakterystyczne budynki i budowle (Okraglak, Arena), pomniki (Bamberki, Mickiewicza, Czerwca 1956).

Badania Znanieckiego leżały też u podstaw wielu podobnych konkursów przeprowadzonych wcześniej we Wrocławiu ${ }^{46}$. Metodę powtórzenia badań po pewnym czasie $\mathrm{w}$ tej samej miejscowości stosowano również $\mathrm{w}$ badaniach na Ziemiach Zachodnich i Północnych, w tym miastach województw zielonogórskiego i opolskiego ${ }^{47}$. Do zagadnienia miasta $\mathrm{w}$ świadomości nawiązywano też $\mathrm{w}$ badaniach miast pogranicza polsko-niemieckiego, w tym $\mathrm{w}$ przeprowadzonym w Słubicach konkursie „Czym jest dla Ciebie miasto Słubice?”, w którym jednym z pytań było zagadnienie „symboli Słubic” i „cechy mieszkańców Słubic"48.

Badania nad „miastem w świadomości” dostarczają informacji na temat stereotypu miasta, w którym wyraża się jego tożsamość. Stereotyp miasta potraktować można, z jednej strony, jako wskaźnik identyfikacji mieszkańców z miastem, z drugiej - jako wizerunek, który budzić ma zainteresowanie z zewnątrz (np. ze strony inwestorów czy przyjezdnych studentów). Można też przyjać, że stereotypy:

- współtworzą tę tożsamość, dostarczając jej układów odniesienia,

- wzmacniają i podtrzymują tożsamość, dostarczając poczucia swojskości (dzięki nim świat jest wypełniony przedmiotami znanymi, „bezpiecznymi”),

- wyrażają naszą tożsamość, gdyż chętnie „na zewnątrz” do tego stereotypu się przyznajemy,

- wskazują na te miejsca w mieście, z którymi chcemy się identyfikować.

Szczególnym miejscem kształtującym tożsamość każdego miasta jest centrum - dla Aleksandra Wallisa „serce miasta”49. Czy obecnie, kiedy mówimy

${ }^{45}$ R. Cichocki, K. Podemski, Miasto w świadomości swoich mieszkańców, Poznań 1999.

${ }^{46}$ B. Jałowiecki (red.), Zwiazani $z$ miastem. Opracowanie $i$ fragmenty wypowiedzi nadestanych na konkurs: „Czym jest dla Ciebie miasto Wrocław”, Wrocław 1970.

${ }^{47}$ A. Kwilecki (red.), 60 lat socjologii poznańskiej, Poznań 1981, s. 18.

${ }^{48} \mathrm{~S}$. Lisiecki, O granicach naturalnych, politycznych, spotecznych $i \ldots$ granicach $w$ gtowie. Szkice do socjologii pogranicza polsko-niemieckiego, Poznań 2009, s. 136-146.

${ }^{49}$ B. Jałowiecki, M. S. Szczepański, op. cit., s. 331. 
o tożsamości ponowoczesnej, w której sprzeciw budzi „wszelkie przywiązanie do miejsc i przeszłości”, miasto ma jeszcze serce? Jeśli odwołamy się do przykładów badań przeprowadzonych w Poznaniu przez Konrada Miciukiewicza, to charakterystyczna wydaje się odpowiedź na pytanie: „Gdzie jest centrum miasta?"50. Jak wykazały jego badania, mieszkańcy Poznania udzielali w zasadzie bardzo podobnych odpowiedzi, wskazując na Stary Rynek, oś łącząca Stary Rynek ze Starym Browarem. Ale byli też badani, którzy nie wiedzieli, gdzie właściwie obecnie znajduje się centrum: „Bóg jeden raczy znać. Poznań jest miastem, które tak na dobrą sprawę nie ma ściśle określonego centrum, bo to jest i ul. Święty Marcin, to jest oczywiście Stary Rynek, ale Rynek pełni raczej funkcje takie zabytkowo-towarzyskie, jest miejscem spotkań. Takiego centrum z prawdziwego zdarzenia, gdzie stoja jakieś domy pod niebo, na dole szaleją fontanny, a w zimie jest lodowisko, jednoznacznie określonego w Poznaniu nie ma"51.

O rozbieżnościach co do lokalizacji centrum miasta mówią też badania przeprowadzone wśród mieszkańców miast ślaskich (Rybnika, Bytomia, Katowic, Rudy Śląskiej, Tychów), które wykazały, że nieco ponad 50\% mieszkańców tych miast twierdziło, że ich miasto „posiada swoje serce” ${ }^{\text {. }}$. Przyczyn problemów ze wskazaniem centrum miasta upatruje się w nowo powstałych wielkich centrach handlowych, które staja się substytutem centrum. W tym kontekście mówi się nawet o kryzysie centrum miasta, o którym wspomniany już Wallis mówił, że to „obszar, który dzięki swoim urbanistycznym i architektonicznym wartościom, pozwala na największą koncentrację publicznych procesów społecznych stanowiących warunek społecznej integracji i rozwoju ludności miasta oraz jego społecznego zaplecza"53.

Szczególnym problemem dla współczesnego centrum są wielkie galerie handlowe (shoppings-malls). Jak wykazują socjologiczne badania nad centrami miast ślaskich (Bytom, Katowice, Ruda Ślaska, Rybnik, Tychy), w większości przypadków centra handlowe stają się substytutem centrum miasta ${ }^{54}$. Szczególnym w tym względzie przypadkiem sa Katowice, gdzie co czwarty badany wskazywał, że centrum miasta przeniosło się do otwartego na terenie zlikwidowanej kopalni Gottwald wielkiego (65 tys. $\mathrm{m}^{2}$ ) Silesia City Center ${ }^{55}$.

Na zakończenie pozwólmy sobie jeszcze na pewną dygresję. Problematyka wartościowania przestrzeni, podobnie jak problem centrum, wpisuje się w toczaccą się obecnie dyskusję na temat „Miasta Europejskiego” jako modelu rozwoju miasta postindustrialnego. Przywołuje się przy tym znaną koncepcję Webera, który w pracy zatytułowanej Die Stadt (1921) uznał, że cechami miasta europejskiego sa:

${ }^{50}$ K. Miciukiewicz, Konstruowanie miejskiej przestrzeni Publicznej. Przemiany ul. Półwiejskiej w latach 1986-2006, Instytut Socjologii UAM, Poznań 2007, praca doktorska.

51 Ibidem, s. 198.

${ }^{52}$ K. Bierwiaczonek, T. Nawrocki, Społeczna percepcja centrum miast ślaskich, w: H. Dymnicka, A. Majer, Wspótczesne miasta, szkice socjologiczne, Łódź 2009, s. 114.

${ }^{53}$ A. Wallis, Informacja i gwar: o miejskim centrum, Warszawa 1979, s. 24.

${ }^{54}$ K. Bierwiaczonek, T. Nawrocki, op. cit., s. 103-127.

55 Ibidem, s. 120. 
- istnienie umocnień (murów miejskich) odrębnych od umocnień feudalnych zamków,

- istnienie rynku miejskiego jako miejsca realizacji miejskiej gospodarki wymiany stanowiącej antytezę feudalnej samowystarczalnej gospodarki typu wiejskiego,

- istnienie własnego, niezależnego sądownictwa miejskiego,

- oparcie społeczno-politycznej organizacji miejskiej na zasadzie dobrowolnej wspólnoty jednostek, różnej od feudalnego systemu dziedziczenia rodowego,

- istnienie autonomii politycznej i samorządności miejskiej opartej na uczestnictwie obywateli miasta ${ }^{56}$.

W debatach na temat Miasta Europejskiego nawiązuje się do przedstawionej powyżej charakterystyki miasta-gminy okresu średniowiecznego i odnosi kategorie wymienione przez Webera do współczesnych przestrzeni i procesów zachodzących w miastach europejskich. Podkreśla się np. takie cechy, jak „zwartość zabudowy” czy „hierarchiczność” (podział na centrum i peryferie). W wymiarze społecznym zaś miasta europejskie to, przede wszystkim, miasta obywatelskie: ,jest to przestrzeń społeczna, w której w pierwszym rzędzie decydują nie więzi rodowe, ale pojedyncze jednostki. Innymi słowy, model "Miasta Europejskiego» to model "miasta obywatelskiego« zarządzanego przez demokratycznie wybrane władze miejskie i opartego na więziach obywatelskich i obywatelskim poczucie wspólnoty" ${ }^{57}$. Do tak zmodyfikowanego modelu Miasta Europejskiego rozumianego jako „społeczny podmiot kolektywny” nawiązuje się w dyskusji na temat polityki miejskiej Unii Europejskiej. Znalazło to swój wyraz w „Karcie Lipskiej na rzecz zrównoważonego rozwoju miast europejskich 2007”, w której „przedstawiono dwa podstawowe paradygmaty polityki rozwoju miast: "zrównoważony rozwój« i »Miasto Europejskie«. W ten sposób dyskurs naukowców i fachowców od rozwoju miast wpływa na praktykę polityczna. Obecnie postulaty rozwoju miast jako »Miasta Europejskiego» stanowią standard polityki rozwoju miast w krajach Europy Zachodniej"58.

W tym miejscu dodać jeszcze można, że do koncepcji Webera nawiązuje się też we współczesnych rozważaniach na temat rewitalizacji miast polskich, o czym świadczą dyskusje podejmowane przez polskich architektów, socjologów i historyków ${ }^{59}$. Wydaje się, że także w tym kontekście warto sięgać do dorobku poznańskich socjologów, w tym do dorobku Floriana Znanieckiego i Janusza Ziółkowskiego.

dr hab. Stanistaw Lisiecki

Profesor Uniwersytetu im. Adama Mickiewicza w Poznaniu

lisiecki@amu.edu.pl

${ }^{56}$ A. Billert, Założenia, modele i planowanie polityki rozwoju miast. Próba konfrontacji dwóch światów jednej Unii Europejskiej, w: K. Derejski, J. Kubera, S. Lisiecki, R. Macyra (red.), Deklinacja odnowy miast. $Z$ dyskusji nad rewitalizacja w Polsce, Poznań 2012, s. 38.

57 Ibidem, s. 39.

58 Ibidem, s. 40.

${ }_{59}$ Zob. K. Derejski, J. Kubera, S. Lisiecki, R. Macyra (red.), op. cit.; iidem (red.), Nowe życie w mieście? Dylematy rewitalizacji, Poznań 2014. 


\title{
FLORIAN ZNANIECKI AND JANUSZ ZIÓŁKOWSKI: \\ THE TRADITION AND ONGOING RESEARCH \\ ON THE EVALUATION OF URBAN SPACE
}

\author{
Sum mary
}

This article presents the specifics of a sociological understanding of space, focusing on the concepts of two Polish researchers in urban sociology - Florian Znaniecki and Janusz Ziółkowski. It discusses the evaluation of space by different social groups and communities which determine the manner and extent of its use. The most important studies of Znaniecki and Ziółkowski are presented and placed in the context of European urban sociology and the Ecological School of Chicago. In the final section, it is shown how sociologists today may refer to the concept of the evaluation of space, especially in contemporary discussions on the identity of cities, the disappearance of city centers and urban renewal. 